\title{
THE FORMATION OF MACROGLOBULIN ANTIBODIES. II. STUDIES ON NEONATAL INFANTS AND OLDER CHILDREN *
}

\author{
By CHESTER W. FINK, WILLIAM E. MILLER, JR., BARBARA DORWARD \\ AND JOSEPH LOSPALLUTO $\dagger$
}

\author{
(From the Departments of Internal Medicine [Rheumatic Diseases Unit], \\ Pediatrics, and Biochemistry, The University of Texas \\ Southwestern Medical School, Dallas, Tex.)
}

(Submitted for publication January 4, 1962 ; accepted March 15, 1962)

In another publication (1), the molecular size of antibodies formed in response to immunization with typhoid-paratyphoid (TPT) vaccine was studied in adult humans. In this report premature infants, immunized shortly after birth, were studied in a similar manner in order to compare this aspect of the immune response in infants and adults. It has been shown (2) that the initial antibodies produced in response to TPT immunization are 19S macroglobulins. The sequence of formation of macroglobulin antibody, followed by $7 \mathrm{~S}$ antibody, has also been observed by Taliaferro, Talmadge, Freter and Stelos (3-7), who showed that in rabbits immunized with sheep or beef red cells the first antibodies formed had an electrophoretic mobility of the $\gamma-1$ type and had a sedimentation coefficient of $18 \mathrm{~S}$. These were followed, in time, by $6 \mathrm{~S}$ antibodies associated with the $\gamma-2$ globulins. Molecules of antibodies of different size in rabbits, produced in response to single protein antigens, have recently been reported (8).

We were also interested in determining the effect of maternally-transferred antibody on the formation by infants of agglutinins to TPT antigens. In addition, the effect of sulfhydryl compounds on the macroglobulin antibodies produced by the premature infant was investigated. It has been suggested that the agglutinin activity of $19 \mathrm{~S}$ typhoid $\mathrm{H}$ antibody of the neonatal infant differs qualitatively from that of the adult after treatment with 2-mercaptoethanol (9).

* Supported by a grant to the Arthritis Clinical Study Center, Parkland Memorial Hospital, from the National Foundation; and by Grant A-2071 from the National Institute of Arthritis and Metabolic Diseases, Bethesda, Md. $\dagger$ Fellow, The Helen Hay Whitney Foundation.

\section{MATERIALS AND METHODS}

Forty-two premature infants were studied. Preimmunization blood was obtained from the umbilical cord or from the infant immediately before immunization. In a number of cases both were obtained. Infants were immunized by intramuscular injection into the anterior thigh of $0.25 \mathrm{ml}$ of a TPT A and B vaccine (Lederle) containing 1 billion organisms of Salmonella typhi per $\mathrm{ml}$ and 250 million organisms of $S$. paratyphi $\mathrm{A}$ and $\mathrm{B}$ per $\mathrm{ml}$. Thirty-one infants received three injections 1 week apart; eleven received only one injection. The first injection was given within 48 hours after birth and in most instances within the first 24 hours. The first blood sample was obtained 1 week after the third injection in most cases. Additional blood samples were obtained before and after booster injections given at varying times after the initial course of immunization.

Fourteen older children, aged 9 months to 8 years, hospitalized for orthopedic rehabilitation or convalescing from primary pulmonary tuberculosis were immunized with three injections of $0.5 \mathrm{ml}$ of TPT vaccine given intramuscularly, 1 week apart. Sera were obtained before immunization and at various times after the third injection.

Blood samples were allowed to clot at $37^{\circ} \mathrm{C}$ and the sera removed. Each serum was diluted with an equal volume of distilled water and dialyzed for 2 days against $0.01 \mathrm{M}$ phosphate buffer at $\mathrm{pH} 8.5$. After dialysis, sera were stored at $-20^{\circ} \mathrm{C}$. The dialyzed sera, usually 1 to $3 \mathrm{ml}$, were fractionated by column chromatography on diethylaminoethyl (DEAE)-cellulose as previously reported $(10,11)$. Proteins were eluted with phosphate buffers of increasing concentration and decreasing $\mathrm{pH}$.

Four chromatographic fractions were obtained. The

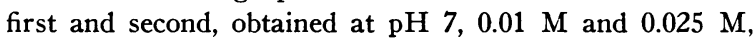
respectively, contained the bulk of the $\gamma$-globulin which was entirely of the 7S variety. The third contained most of the albumin and the $\alpha$ - and $\beta$-globulins. In the last peak were the 19S $\gamma$-globulins in addition to other proteins, with some contamination by $7 \mathrm{~S} \gamma$-globulin. There was almost complete separation of the $7 \mathrm{~S}$ and $19 \mathrm{~S} \gamma$ globulin, however, and they could be tested for individually.

The sera and chromatographic fractions were tested for agglutinating antibody by the standard serial dilution 
TABLE I

\begin{tabular}{|c|c|c|c|c|c|c|c|c|c|}
\hline \multirow[b]{2}{*}{ Age } & \multirow[b]{2}{*}{ Infants } & \multicolumn{2}{|c|}{ Typhoid O } & \multicolumn{2}{|c|}{ Typhoid H } & \multicolumn{2}{|c|}{ Paratyphoid A } & \multicolumn{2}{|c|}{ Paratyphoid B } \\
\hline & & $7 \mathrm{~S}$ & $19 S$ & $7 \mathrm{~S}$ & $19 \mathrm{~S}$ & $7 \mathrm{~S}$ & $19 \mathrm{~S}$ & $7 \mathrm{~S}$ & $19 \mathrm{~S}$ \\
\hline $\begin{array}{c}w k s \\
3.1 \\
(2-5)\end{array}$ & $\begin{array}{l}\text { no. } \\
31\end{array}$ & 0 & $(0-40)$ & $\begin{array}{c}1 \\
(0-20)\end{array}$ & $\begin{array}{c}323 \\
(10-2,560)\end{array}$ & $\begin{array}{c}12 \\
(0-40)\end{array}$ & $\begin{array}{c}490 \\
(40-2,560)\end{array}$ & $\begin{array}{c}24 \\
(0-160)\end{array}$ & $\begin{array}{c}523 \\
(20-5,120)\end{array}$ \\
\hline $\begin{array}{c}8.0 \\
(6-10)\end{array}$ & 14 & 0 & 0 & $\begin{array}{c}17 \\
(0-80)\end{array}$ & $\begin{array}{c}61 \\
(0-160)\end{array}$ & $\begin{array}{c}49 \\
(0-160)\end{array}$ & $\begin{array}{r}65 \\
(0-320)\end{array}$ & $\begin{array}{c}90 \\
(0-320)\end{array}$ & $\begin{array}{r}47 \\
(0-160)\end{array}$ \\
\hline $\begin{array}{c}13.0 \\
(11-15)\end{array}$ & 10 & 0 & 0 & $\begin{array}{c}3 \\
(0-10)\end{array}$ & $\begin{array}{r}11 \\
(0-20)\end{array}$ & $\begin{array}{c}56 \\
(0-160)\end{array}$ & $\begin{array}{c}11 \\
(0-20)\end{array}$ & $\begin{array}{c}91 \\
\left(10^{-160}\right)\end{array}$ & $(0-20)^{5}$ \\
\hline $\begin{array}{c}18.4 \\
(16-20)\end{array}$ & 8 & 0 & 0 & $\begin{array}{c}3 \\
(0-10)\end{array}$ & $(0-20)^{4}$ & $\begin{array}{c}48 \\
(20-80)\end{array}$ & $(0-10)^{1}$ & $\begin{array}{c}130 \\
(40-320)\end{array}$ & $(0-10)^{3}$ \\
\hline
\end{tabular}

method (12), starting with a dilution of 1:10. Tests were performed for antibody to each of the four antigens administered, $S$. typhi $\mathrm{O}$ and $\mathrm{H}$, and $S$. paratyphi $\mathrm{A}$ and B. ${ }^{1}$ The antigens were used at a 1:10 dilution. Tubes were shaken, incubated at $37^{\circ} \mathrm{C}$ for 2 hours, and placed in the refrigerator overnight. The titer was recorded as the highest dilution showing definite agglutination.

In order to determine the effect of sulfhydryl agents, the pertinent chromatographic fractions from each of a number of sera with high agglutination titers were tested in duplicate. In one set of tubes, antibody and antigen were diluted in the usual manner in phosphate-buffered saline, $\mathrm{pH}$ 7.0. In another set, 2-mercaptoethanol (ME) was added to the phosphate-buffered saline used in the dilution of antibody and antigens. In most cases the final concentration of $\mathrm{ME}$ was $0.05 \mathrm{M}$. The two sets of tubes were treated identically and, except for the $\mathrm{ME}$, the method of testing was the same as that otherwise used.

In addition, one serum was treated with $\mathrm{ME}$ under diverse conditions and tested simultaneously with controls lacking $\mathrm{ME}$ as follows. 1) A sample of undiluted test serum was added to an equal amount of $0.1 \mathrm{M} \mathrm{ME}$ and the mixture allowed to stand at $4^{\circ} \mathrm{C}$ for 24 hours. Agglutination tests were then performed after dilution of antibody and antigen: a) in phosphate-buffered saline,

1 Supplied by the Texas State Department of Health Laboratories, Austin, Tex. and $b$ ) in phosphate-buffered saline after the initial 1:10 dilution was made in $0.05 \mathrm{M}$ ME. 2) A sample of undiluted test serum and serum diluted 1:5 with buffered saline were mixed with an equal volume of $0.05 \mathrm{M} \mathrm{ME}$ and dialyzed for 24 hours against $0.05 \mathrm{M} \mathrm{ME}$. Agglutination tests were then carried out after serial dilution of the serum in the saline buffer.

\section{RESULTS}

The antibody response obtained in a group of premature infants with no preimmunization titer is seen in Table I. One week after the third injection, when the infants were about 3 weeks old, virtually the entire agglutinating titer was found in the 19S antibody fraction. After the initial rise there was a slow fall in titer, which was accompanied by a change in the type of antibody present from primarily $19 \mathrm{~S}$ to the $7 \mathrm{~S}$ type. This change occurred most rapidly with paratyphoid B and least rapidly with typhoid $\mathrm{H}$.

Nineteen of the 43 preimmunization sera (usually cord blood) contained agglutinins to one or more of the antigens. In none of the infants was maternally-transferred antibody to typhoid $\mathrm{O}$ ob-

TABLE II

Inhibition of antibody response by maternally-transferred antibody

\begin{tabular}{|c|c|c|c|c|c|c|c|c|}
\hline \multirow[b]{2}{*}{ Age } & \multicolumn{2}{|c|}{ Typhoid $\mathrm{O}$} & \multicolumn{2}{|c|}{ Typhoid H } & \multicolumn{2}{|c|}{ Paratyphoid A } & \multicolumn{2}{|c|}{ Paratyphoid B } \\
\hline & $7 \mathrm{~S}$ & $19 \mathrm{~S}$ & $7 \mathrm{~S}$ & $\overline{19 \mathrm{~S}}$ & $7 \mathrm{~S}$ & $\overline{19 S}$ & $7 \mathrm{~S}$ & 19S \\
\hline${ }_{3}{ }^{2}$ (cord blood) & $\begin{array}{l}0 \\
0 \\
0\end{array}$ & $\begin{array}{l}0 \\
0 \\
0\end{array}$ & $\begin{array}{r}20 \\
20 \\
0\end{array}$ & $\begin{array}{l}0 \\
0 \\
0\end{array}$ & $\begin{array}{l}20 \\
40 \\
10\end{array}$ & $\begin{array}{l}0 \\
0 \\
0\end{array}$ & $\begin{array}{r}0 \\
40 \\
80\end{array}$ & $\begin{array}{r}0 \\
320 \\
0\end{array}$ \\
\hline \multicolumn{9}{|c|}{ Booster immunization at 13 weeks } \\
\hline 17 & 0 & 0 & 0 & 0 & 20 & 0 & 160 & 0 \\
\hline
\end{tabular}


TABLE III

Mean agglutinin titers in 16 infants before and after booster immunization with TPT

\begin{tabular}{|c|c|c|c|c|c|c|c|c|}
\hline & \multicolumn{2}{|c|}{ Typhoid O } & \multicolumn{2}{|c|}{ Typhoid H } & \multicolumn{2}{|c|}{ Paratyphoid A } & \multicolumn{2}{|c|}{ Paratyphoid B } \\
\hline & $7 \mathrm{~S}$ & $19 \mathrm{~S}$ & $7 \mathrm{~S}$ & $19 \mathrm{~S}$ & $7 \mathrm{~S}$ & $19 \mathrm{~S}$ & $7 \mathrm{~S}$ & $19 \mathrm{~S}$ \\
\hline $\begin{array}{l}\quad \text { wks } \\
\text { Prebooster; } \\
\text { average age } \\
16.7 \\
(6-24)\end{array}$ & 0 & 0 & $\begin{array}{c}11 \\
(0-40)\end{array}$ & $\begin{array}{c}7 \\
(0-20)\end{array}$ & $\begin{array}{c}83 \\
(0-320)\end{array}$ & $\stackrel{2}{2}$ & $\begin{array}{c}150 \\
(0-320)\end{array}$ & $\begin{array}{c}7 \\
(0-40)\end{array}$ \\
\hline $\begin{array}{l}\text { Postbooster; } \\
\text { average age } \\
21.5 \\
(13-29)\end{array}$ & 0 & $\begin{array}{c}1 \\
(0-20)\end{array}$ & $\begin{array}{c}77 \\
(0-320)\end{array}$ & $\begin{array}{c}25 \\
(0-80)\end{array}$ & $\begin{array}{c}127 \\
(40-320)\end{array}$ & $\begin{array}{c}5 \\
(0-20)\end{array}$ & $\begin{array}{c}342 \\
(40-1,280)\end{array}$ & $\begin{array}{c}6 \\
(0-40)\end{array}$ \\
\hline
\end{tabular}

served. Maternally-transferred antibodies to other antigens, however, were in all cases of the $7 \mathrm{~S}$ variety.

In addition, the presence of maternally-transferred antibody appeared to inhibit active antibody synthesis, but only in the case of the specific antigen-antibody system involved. Where preimmunization antibodies were present, they were usually for typhoid $\mathrm{H}$ and paratyphoid $\mathrm{A}$ or for typhoid $\mathrm{H}$ alone. Maternal paratyphoid $\mathrm{B}$ antibody was found in only one infant, occurring simultaneously with antibody to typhoid $\mathrm{H}$ and paratyphoid A. A pattern typical of infants who had antibody before immunization is shown in Table II. Typhoid $\mathrm{H}$ and paratyphoid A agglutinins were present in this serum before immunization. The results indicate that after immunization there was no significant antibody formation in response to typhoid $\mathrm{H}$ and paratyphoid $\mathrm{A}$, for which maternally-transferred antibody was present. Where no transferred antibody was present, as in the case of paratyphoid $\mathrm{B}$, high titers of antibody resulted. The antibody formed in this instance was predominantly the $19 \mathrm{~S}$ type at 3 weeks of age. The failure of antibody to typhoid $O$ to appear in this infant is not unusual, since only one out of every four immunized infants responded with a measurable titer for this antigen at any time. When typhoid $\mathrm{O}$ agglutinins were present they were always of the 19S type, as observed in adults (1), and their titers were always low.

By 13 weeks of age, the titer of maternallytransferred antibody to typhoid $\mathrm{H}$ and paratyphoid A had decreased. The $19 \mathrm{~S}$ paratyphoid B antibody had dropped to titers below $1: 10$, while the 7S paratyphoid $\mathrm{B}$ was essentially unchanged from the level at 3 weeks (one-tube changes were not thought to be significant). The inhibition by maternally-transferred antibody of active antibody synthesis persisted even after a booster immunization given at 13 weeks. This was most clearly demonstrated in the case of typhoid $\mathrm{H}$ where there was no detectable antibody present 4 weeks after the booster was given, in spite of a negative prebooster titer. The titer to paratyphoid $\mathrm{A}$ also showed no rise. The failure of a significant secondary response to paratyphoid B was similar to that seen in other cases where the prebooster agglutinin titer was rather high.

In the 19 infants with maternally-transferred antibody, this antibody was present 28 times for

TABLE IV

Mean agglutinin titers after primary TPT immunization of 14 older infants and children

\begin{tabular}{|c|c|c|c|c|c|c|c|c|}
\hline \multirow{2}{*}{$\begin{array}{l}\text { Av. time } \\
\text { after initial } \\
\text { immuniz. }\end{array}$} & \multicolumn{2}{|c|}{ Typhoid O } & \multicolumn{2}{|c|}{ Typhoid H } & \multicolumn{2}{|c|}{ Paratyphoid A } & \multicolumn{2}{|c|}{ Paratyphoid B } \\
\hline & $7 \mathrm{~S}$ & 19S & $7 \mathrm{~S}$ & $19 \mathrm{~S}$ & $7 \mathrm{~S}$ & $19 \mathrm{~S}$ & $7 \mathrm{~S}$ & $19 \mathrm{~S}$ \\
\hline$w k s$ & & & & & & & & \\
\hline $\begin{array}{c}3.3 \\
(3-5)\end{array}$ & 0 & $\begin{array}{c}26 \\
(0-160)\end{array}$ & $\begin{array}{c}1 \\
(0-10)\end{array}$ & $\begin{array}{c}226 \\
(40-640)\end{array}$ & $\begin{array}{c}12 \\
(0-40)\end{array}$ & $\begin{array}{c}260 \\
(40-640)\end{array}$ & $\begin{array}{c}28 \\
(0-160)\end{array}$ & $\begin{array}{c}234 \\
(80-640)\end{array}$ \\
\hline $\begin{array}{c}12.0 \\
(11-17)\end{array}$ & 0 & $\begin{array}{c}10 \\
(0-40)\end{array}$ & $\begin{array}{c}1 \\
(0-10)\end{array}$ & $\begin{array}{c}66 \\
(10-160)\end{array}$ & $\begin{array}{c}19 \\
(0-40)\end{array}$ & $\begin{array}{c}57 \\
(20-160)\end{array}$ & $\begin{array}{c}29 \\
(0-80)\end{array}$ & $\begin{array}{c}31 \\
(10-80)\end{array}$ \\
\hline
\end{tabular}


TABLE V

Effect of 2-mercaptoethanol (ME) on antibody titers in 16 premature infants *

\begin{tabular}{|c|c|c|c|c|c|c|c|c|}
\hline & \multicolumn{2}{|c|}{ Typhoid O } & \multicolumn{2}{|c|}{ Typhoid H } & \multicolumn{2}{|c|}{ Paratyphoid A } & \multicolumn{2}{|c|}{ Paratyphoid B } \\
\hline & $7 \mathrm{~S}$ & $19 \mathrm{~S}$ & $7 \mathrm{~S}$ & $19 \mathrm{~S}$ & $7 \mathrm{~S}$ & $19 \mathrm{~S}$ & $7 \mathrm{~S}$ & $19 \mathrm{~S}$ \\
\hline $\begin{array}{c}\text { Without } \\
\text { 2-ME }\end{array}$ & 0 & $\begin{array}{c}4 \\
(0-20)\end{array}$ & $\begin{array}{c}4 \\
(0-20)\end{array}$ & $\begin{array}{c}427 \\
(40-2,560)\end{array}$ & $\begin{array}{c}39 \\
(0-160)\end{array}$ & $\begin{array}{c}565 \\
(80-2,560)\end{array}$ & $\begin{array}{c}77 \\
(0-320)\end{array}$ & $\begin{array}{c}575 \\
(80-2,560)\end{array}$ \\
\hline $\begin{array}{l}\text { With } \\
2-\mathrm{ME}\end{array}$ & 0 & 0 & $\begin{array}{c}4 \\
(0-20)\end{array}$ & $\begin{array}{r}10 \\
(0-40)\end{array}$ & $\begin{array}{c}21 \\
(0-80)\end{array}$ & $\begin{array}{r}23 \\
(10-80)\end{array}$ & $\begin{array}{c}41 \\
(0-160)\end{array}$ & $\begin{array}{c}24 \\
(10-80)\end{array}$ \\
\hline
\end{tabular}

* Tests run in duplicate. ME was added to the phosphate-buffered saline used to dilute antibody and antigens so that the final concentration was $0.05 \mathrm{M}$.

one of the antigens, typhoid $\mathrm{H}$ or paratyphoid $\mathrm{A}$ or $\mathrm{B}$. In 17 of the 28 times, immunization was followed by no increase in the serum titer, and no $19 \mathrm{~S}$ antibody appeared. However, in the other 11 times, low titers of antibody $(1: 10$ or $1: 20)$ were found in the $19 \mathrm{~S}$ fraction after immunization; but there was no rise in the titer of the unfractionated serum. These low $19 \mathrm{~S}$ titers disappeared rapidly and did not recur after booster immunization.

The effect of booster injection on infants 6 to 24 weeks old is illustrated in Table III. For each antigen except typhoid $\mathrm{O}$, no significant increase in the 19S antibody titers was observed. On the other hand, after booster immunization, increased levels of antibodies for paratyphoids A and B and typhoid $\mathrm{H}$ were associated with the $7 \mathrm{~S}$ fraction.

The results obtained after initial immunization of a group of 14 older children between 9 months and 8 years of age are shown in Table IV. Sera obtained before immunization contained agglutinins for typhoid $\mathrm{H}$ in low titer in 9 of the 14 patients. Agglutinins to the other three antigens were seen less frequently. Immune sera were drawn 1 week after the third TPT injection and a second postimmunization serum sample was obtained about 9 weeks later. Comparison of the results obtained in neonatal infants with those in the older children indicates that at about 12 to 13 weeks after initial immunization, the neonates showed a striking change from $19 \mathrm{~S}$ to $7 \mathrm{~S}$ paratyphoid $A$ and $B$ agglutinins (Table I). The older children (Table IV) showed a much lower proportion of the total antibody activity in the $7 \mathrm{~S}$ fraction. This difference between neonates and older children was not apparent in the case of the typhoid $\mathrm{H}$ agglutinins, although there was a sharper decline in the amount of typhoid H 19S agglutinin in the neonatal infants.

The effect of 2-mercaptoethanol on antibody

TABLE VI

Effect of 2-mercaptoethanol on $19 S$-globulin (Patient Wi)

\begin{tabular}{|c|c|c|c|}
\hline Test conditions & Typh. H & PTyph. A & PTyph. B \\
\hline A. Routine test; no $\mathrm{ME}$ & 1,280 & 1,280 & 2,560 \\
\hline $\begin{array}{l}\text { B. ME added to buf. saline used to dilute } \\
\text { antigens and antibody; final conc. } 0.05 \mathrm{M}\end{array}$ & 10 & 10 & 10 \\
\hline $\begin{array}{l}\text { C. } 0.25 \mathrm{ml} \text { serum }+0.25 \mathrm{ml} 0.1 \mathrm{M} \mathrm{ME} \text {; } \\
\text { left } 24 \mathrm{hrs} \text { at } 4^{\circ} \mathrm{C} ; \text { diluted to } 2.5 \mathrm{ml} \text { with } \\
\text { buf. saline; buf. saline used for dilutions } \\
\text { of antigens and antibody }\end{array}$ & 40 & 20 & 40 \\
\hline $\begin{array}{l}\text { D. Same as C except dilution to } 2.5 \mathrm{ml} \\
\text { done with } 0.05 \mathrm{M} \mathrm{ME}\end{array}$ & 20 & 20 & 20 \\
\hline $\begin{array}{l}\text { E. } 0.5 \mathrm{ml} 1: 5 \text { diluted (buf. saline) serum } \\
+0.5 \mathrm{ml} 0.05 \mathrm{M} \mathrm{ME;} \mathrm{dialyzed} 24 \mathrm{hrs} \\
\text { against } 0.05 \mathrm{M} \mathrm{ME} \text {; dilutions of antigens } \\
\text { and antibody done in buf. saline }\end{array}$ & 20 & 20 & 20 \\
\hline $\begin{array}{l}\text { F. Same as E except used } 0.5 \mathrm{ml} \text { of un- } \\
\text { diluted serum }\end{array}$ & 20 & 20 & 20 \\
\hline
\end{tabular}


activities is shown in Table V. There was little effect on the $7 \mathrm{~S}$ antibody present, the slight fall in average titer being within experimental error. However, a striking decrease in titers with almost complete disappearance of agglutinating activity was observed after treatment of the $19 \mathrm{~S}$ fraction with $0.05 \mathrm{M}$ ME. One serum (Wi), obtained 1 week after the third injection of the primary series, was tested with and without ME under multiple test conditions. All the antibody for which we tested was of the $19 \mathrm{~S}$ type. The test conditions and reciprocal agglutinin titers are shown in Table VI. Under all test conditions there was a fall in agglutinating activity to very low levels.

\section{DISCUSSION}

The failure of macroglobulin antibodies such as typhoid $\mathrm{O}$ to traverse the placenta in significant quantity has been documented $(2,13)$. No decrease in the infant:mother ratio of total $\gamma$-globulin, predominantly $7 \mathrm{~S}$ in type, has been noted. In fact, the data available suggest that the infant has a slightly higher average serum concentration of $\gamma$-globulin than has the mother $(14,15)$. Thus it appears that $7 \mathrm{~S}$ protein traverses the placenta and that the protection provided the newborn by antibody passively transferred from the mother would vary according to whether the maternal antibody is predominantly 7S or $19 \mathrm{~S}$. Antibody to the $\mathrm{O}$ antigen of Escherichia coli 0111 appears to pass the placental barrier poorly (16). If this, like antibody to typhoid $\mathrm{O}$, is a $19 \mathrm{~S}$ macroglobulin, it may well be a characteristic of antibodies to somatic coliform antigens.

The concentration of $\gamma$-globulin in the serum of infants gradually falls during the first few weeks of life $(14,17,18)$, but there is some question as to whether active $\gamma$-globulin synthesis takes place during this period. Although no measurements of total $\gamma$-globulin were made in the infants studied, there is no doubt that they were able to produce antibodies in response to the antigens of TPT vaccine. Measurable titers were found in most newborn infants tested 1 week after the first injection, i.e., when the infants were 1 week old. Smith (19) found similar results with typhoid $\mathrm{H}$ antigen. Others have observed good response in young infants to different antigens (20-22), although in some cases the response seemed inferior to that seen in older children. Thus, although the serum concentration of $\gamma$-globulin falls in the first weeks of life, the infant is capable of response to multiple antigens.

The presence of maternally-transferred antibody appeared to prevent active antibody synthesis to the specific antigen without apparent interference with the other antigen-antibody systems tested. Thus, in the patient shown in Table II, a passively acquired titer of $1: 20$ for typhoid $\mathrm{H}$ inhibited active antibody formation in response to the antigen, while at the same time a high titer was produced to paratyphoid $\mathrm{B}$ antigen for which there was no preimmunization titer. This inhibition seemed to persist after a booster immunization given at 13 weeks, at a time when the typhoid $\mathrm{H}$ titer had fallen below measurable levels. Since the passively transferred antibody. was always of the 7S type and initially the actively formed antibody was predominantly $19 \mathrm{~S}$, it may be concluded that the low molecular weight $(7 \mathrm{~S})$ antibody globulin inhibited synthesis not only of the 7S antibody but also of the (19S) antibody.

The inhibitory effect of maternal antibody has previously been demonstrated with poliomyelitis (23) and diphtheria-pertussis-tetanus immunization (24). The duration of the inhibition in the present study has not been determined, but active antibody formation was not observed in infants with passively acquired antibody even after booster injection. The latest postbooster serum studied was obtained at 29 weeks of age in an infant who had maternal antibody to typhoid $\mathrm{H}$ and paratyphoid $\mathrm{A}$ antigens. At the time of boosting, these antibodies had decreased to nonmeasurable levels, yet there was no antibody response. In the same individual, antibody was produced, both on initial immunization and after booster, to paratyphoid $\mathrm{B}$ for which there were no measurable passively transferred agglutinins. Thus, in some cases, inhibition of active synthesis could result in failure to produce protective antibody for several months after birth despite administration of the usual amounts of vaccine. A similar effect was observed by Uhr and Baumann (25) in guinea pigs injected with horse antitoxin at the same time as, or as long as $\mathbf{5}$ days after, primary immunization with diphtheria toxoid. Inhibition of antibody formation was found with the use of complexes formed in antibody excess (25). 
These authors also demonstrated suppression of the anamnestic response to diphtheria toxoid by the administration of heterologous antitoxin and also a smaller suppression by homologous antitoxin (26). These observations in experimental animals may well explain the partial inhibition of TPT antibody formation after secondary immunization of infants who have high titers of antibody prior to the booster injection of vaccine.

Typhoid O agglutinins were exclusively $19 \mathrm{~S}$ in all infants, older children, and adults (1) tested, whereas the other three antibodies became predominantly $7 \mathrm{~S}$ to a greater or lesser extent with time. As yet no explanation for this difference is available. In infants, after primary immunization, 19S paratyphoid B agglutinins decreased rapidly, and $7 \mathrm{~S}$ antibody became the predominant type so that by 3 months of age almost no $19 \mathrm{~S}$ agglutinins were found. This change in antibody type occurred somewhat more slowly with paratyphoid A, but there was a much slower change in antibody type in the case of typhoid $\mathrm{H}$ antigen. The changes in adults occurred at a much less rapid rate (1).

Other studies $(19,27)$ indicate that the human newborn has few if any plasma cells in the bone marrow, the lamina propria of the ileum and appendix, or in lymph nodes proximal to sites of injection of typhoid-paratyphoid vaccine. However, the fact that antibody can be produced by the newborn during this period suggests that the plasma cell may not be its site of origin. It is possible that the striking differences in the rate of change from 19S to $7 \mathrm{~S}$ antibody production observed between the infants and adults may well be due to antibody synthesis in different types of cells. The 7S antibodies produced in the infants studied appeared at an age when plasma cells can usually be seen. Since few or no $19 \mathrm{~S}$ agglutinins were formed after booster immunization at 3 months, the cell type which produced antibody up to 3 weeks of age, and which may be the sole source of this particular antibody, may have declined in number to the point where antibody production can no longer be observed. No evidence is available to support this possibility.

In all groups studied, the agglutinin activity of the macroglobulin antibody was markedly diminished after exposure to $\mathrm{ME}$ under a variety of conditions. These results confirm the presence of
19S antibodies. The sensitivity of the $19 \mathrm{~S}$ agglutinins to $\mathrm{ME}$ indicates that the dissociated 7S units of these macroglobulin antibodies have little or no agglutinin activity. The disparity of these results with those reported (19) has not been reconciled.

\section{SUMMARY}

1. Premature infants and older children produce high molecular weight antibodies (19S) in response to initial immunization with typhoidparatyphoid vaccine.

2. Maternally-transferred antibody is always of the low molecular weight (7S) type and appears to inhibit active antibody synthesis for the specific antigen-antibody system involved. In some cases this inhibition persists for many weeks.

3. Typhoid $\mathrm{O}$ agglutinins are found only in the 19S fraction in both infants and older children, and no change in molecular size occurs with time or secondary immunization.

4. In premature infants the change from $19 \mathrm{~S}$ to $7 \mathrm{~S}$ antibody takes place rapidly. At an average age of 13 weeks paratyphoid $\mathrm{A}$ and $\mathrm{B}$ antibodies are predominantly $7 \mathrm{~S}$, while the changes in typhoid $\mathrm{H}$ antibody are somewhat slower. Booster immunization elicits almost exclusively $7 \mathrm{~S}$ antibody.

5. The type of antibody formation in older children seems to resemble more closely that of the adult than that of the premature infant.

6. The agglutinating activity of $19 \mathrm{~S}$ antibodies is eliminated by treatment with mercaptoethanol under a variety of conditions.

\section{REFERENCES}

1. LoSpalluto, J., Miller, W., Jr., Dorward, B., and Fink, C. W. The formation of macroglobulin antibodies. I. Studies on adult humans. J. clin. Invest. 1962, 41, 1415.

2. Smith, R. T. Immunity in infancy. Pediat. Clin. N. Amer. 1960, 7, 269.

3. Taliaferro, W. H., and Talmage, D. W. Antibodies in the rabbit with different rates of metabolic decay. J. infect. Dis. 1956, 99, 21.

4. Talmage, D. W., Freter, G. G., and Taliaferro, W. H. Two antibodies of related specificity but different hemolytic efficiency separated by centrifugation. J. infect. Dis. 1956, 98, 300.

5. Stelos, P., and Talmage, D. W. The separation by starch electrophoresis of two antibodies to sheep 
red cells differing in hemolytic efficiency. J. infect. Dis. 1957, 100, 126.

6. Stelos, P. Comparative study of rabbit hemolysins to various antigens. I. Hemolysins to beef red cells. J. infect. Dis. 1958, 102, 103.

7. Stelos, P., and Taliaferro, W. H. Comparative study of rabbit hemolysins to various antigens. II. Hemolysins to the Forssman antigen of guinea pig kidney, human type A red cells and sheep red cells. J. infect. Dis. 1959, 104, 105.

8. Bauer, D. C., and Stavitsky, A. B. On the different molecular forms of antibody synthesized by rabbits during the early response to a single injection of protein and cellular antigens. Proc. nat. Acad. Sci. (Wash.) 1961, 47, 1667.

9. Smith, R. T. Qualitative differences in the immune response of infants and adults receiving salmonella vaccines. J. clin. Invest. 1960, 39, 1029.

10. LoSpalluto, J., and Ziff, M. Chromatographic studies of the rheumatoid factor. J. exp. Med. 1959, 110, 169.

11. LoSpalluto, J., Chegoriansky, J., Lewis, A., and Ziff, M. Chromatographic properties of gamma globulin: Behavior of serum gamma macroglobulins. J. clin. Invest. 1960, 39, 473.

12. Kolmer, J. A., Spaulding, E. H., and Robinson, H. W. Approved Laboratory Technic, 5th ed. New York, Appleton-Century-Crofts, 1951.

13. Franklin, E. C., and Kunkel, H. G. Comparative levels of high molecular weight (19S) gamma globulin in maternal and umbilical cord sera. J. Lab. clin. Med. 1958, 52, 724.

14. Oberman, J. W., Gregory, K. O., Burke, F. G., Ross, S., and Rice, E. C. Electrophoretic analysis of serum proteins in infants and children. I. Normal values from birth to adolescence. New Engl. J. Med. 1956, 255, 743.

15. Orlandini, T., O., Sass-Kortsak, A., and Ebbs, J. H. Serum gamma globulin levels in normal infants. Pediatrics 1955, 16, 575.

16. Sussman, S. The passive transfer of antibodies to Escherichia coli 0111 : B4 from mother to offspring. Pediatrics 1961, 27, 308.

17. Gitlin, D., Gross, P. A. M., and Janeway, C. A. The gamma globulins and their clinical significance.
I. Chemistry, immunology and metabolism. New Engl. J. Med. 1959, 260, 21.

18. Trevorrow, V. E. Concentration of gamma-globulin in the serum of infants during the first 3 months of life. Pediatrics 1959, 24, 746.

19. Smith, R. T. Response to active immunization of human infants during the neonatal period in Ciba Foundation Symposium on Cellular Aspects of Immunity. Boston, Little, Brown, 1960, pp. 348368.

20. Dancis, J., Osborn, J. J., and Kunz, H. W. Studies of the immunology of the newborn infant. IV. Antibody formation in the premature infant. Pediatrics 1953, 12, 151.

21. Di Sant'Agnese, P. A. Combined immunization against diphtheria, tetanus, and pertussis in newborn infants. I. Production of antibodies in early infancy. Pediatrics 1949, 3, 20.

22. Barrett, C. D., Jr., Timm, E. A., Molner, J. G., Wi1ner, B. I., Anderson, C. P., Carnes, H. E., and McLean, I. W., Jr. Multiple antigen for immunization against poliomyelitis; diphtheria, pertussis, and tetanus: I. Response of infants and young children to primary immunization; preliminary report. J. Amer. med. Ass. 1958, 167, 1103.

23. Perkins, F. T., Yetts, R., and Gaisford, W. Serological response of infants to poliomyelitis vaccine. Brit. med. J. 1958, 2, 68.

24. Osborn, J. J., Dancis, J., and Julia, J. F. Studies of the immunology of the newborn infant. II. Interference with active immunization by passive transplacental circulating antibody. Pediatrics 1952, 10, 328.

25. Uhr, J. W., and Baumann, J. B. Antibody formation. I. The suppression of antibody formation by passively administered antibody. J. exp. Med. 1961, 113,935 .

26. Uhr, J. W., and Baumann, J. B. Antibody formation. II. The specific anamnestic antibody response. J. exp. Med. 1961, 113, 959.

27. Bridges, R. A., Condie, R. M., Zak, S. J., and Good, R. A. The morphologic basis of antibody formation development during the neonatal period. J. Lab. clin. Med. 1959, 53, 331. 